\title{
Historical Jesus research and relevance in South Africa
}

Author:

Pieter J.J. Botha ${ }^{1}$

\author{
Affiliation: \\ ${ }^{1}$ Department of New \\ Testament and Early \\ Christian Studies, University \\ of South Africa, South Africa
}

Correspondence to:

Pieter J.J. Botha

e-mail:

bothapjj@unisa.ac.za

\section{Postal address:}

Department of New

Testament \& Early Christian

Studies, University of South

Africa, PO Box 392, Pretoria,

0003, South Africa

\section{Keywords:}

historical Jesus; South

African scholarship; New

Testament scholarship;

theological discourse; South

African theological study

Dates:

Received: 19 Jan. 2009

Accepted: 16 Mar. 2009

Published: 08 June 2009

How to cite this article: Botha, P.J.J., 2009, 'Historical Jesus research and relevance in South Africa', HTS

Teologiese Studies/Theological

Studies 65(1), Art. \#154, 11

pages. DOI: $10.4102 /$ hts.

v65i1.154

\section{This article is available}

at:

http://www.hts.org.za (c) 2009. The Authors.

Licensee: OpenJournals

Publishing. This work

is licensed under the

Creative Commons

Attribution License

\section{ABSTRACT}

A brief review of significant developments in South African historical Jesus research during the past three decades is given. Although historical Jesus investigations are not characteristic or even dominant in South African New Testament scholarship, some of the achievements of the scholars working in this field are not only significant contributions to the discipline but are also of considerable relevance to the challenges facing biblical scholarship in general in the South African context. South African historical Jesus publications show a distinct development from the almost unproblematic application of Jesus' words and actions at the earlier stage to a sophisticated and nuanced juxtaposing and interrelating of modern and ancient settings at the present time. It is suggested that these developments can contribute to the exploration of alternative and appropriate theological discourses.

\section{INTRODUCTION}

Any review of New Testament scholarship in South Africa reveals that historical Jesus research is not very typical of the discipline. ${ }^{1}$ Although Van Aarde (1993a; 1993b) and Craffert (2003b) have previously reviewed historical Jesus research, this paper is an attempt to situate these investigations in the South African context. My review focuses on the past three decades, and aims to present a representative overview of developments.

There is a reticence towards historical Jesus research in South Africa. South African biblical scholars have published widely on various topics, and have gained international repute on many terrains, such as modern linguistic approaches to the Greek of the New Testament, ${ }^{2}$ discourse analysis (Holgate \& Starr 2006:48), study of the Gospel of John, and exegesis of Pauline Letters. The historical Jesus, however, has never been of much interest among South African scholars, despite the efforts of a few talented researchers since the last quarter of the twentieth century.

Innumerable and powerful forces determine the practice of scholarship in any context, and a review of the current state of a discipline must at least briefly mention some of them in order to properly contextualise such research. Of course, the complexity of such determinants demands extensive study, which is not possible here. Yet, any discussion of the current state of historical Jesus research in South Africa must acknowledge our troubled and disturbing past and the distortions of the current sociopolitical context created thereby. Against this backdrop I would identify two particular factors as relevant to understanding our history of biblical research: a quest for usefulness, and an ambiguous attitude towards historical criticism. Similar issues also play a role in other contexts, but probably not to the extent nor in the striking combination that we find here.

Biblical scholars in the South African context have been (and still are) intensely aware of the perversions created by the country's political history, and there is a very strong drive noticeable in biblical scholarship to be relevant to our context. Consequently, a dominant aspect of historical Jesus research is that academic work relating to Jesus of Nazareth must be more than mere research.

South African New Testament scholarship is often criticised for being overly concerned with methodology and theory. ${ }^{3}$ What is usually ignored in such criticism is that the root of this concern is a deeply practical one: to find academic ways to provide relevant scholarship that can have an impact on our communities (with this reminder I am not saying anything about the success and/or actual legitimacy of many of these endeavours).

The second aspect, ambiguity towards historical criticism, relates to a complex web of issues, and any summarising reference to it must distort the matter somewhat. The political system of apartheid was created by a patriarchal, authoritarian, positivistic, and anti-libertarian mindset. In its turn, the system fostered these values, and tragically ensconced them in a very wide base, cutting right across most societal and cultural boundaries. These authoritarian and positivistic trends tend to influence attitudes towards history directly or indirectly. Historical 'truth' may be emphasised, and frequently appealed to, but it mostly emerges that only 'useful' history is invoked. Critical historiography is deemed with deep suspicion, especially revisionist history. These ambiguous attitudes toward history are also evident in several South African discussions of historical Jesus research. Conventional South African New Testament scholarship is in fact extremely weary of history.

Historical criticism has clearly not been accepted or digested by the South African theological establishment or community of scholars. Often it is still viewed with scepticism and as something which must either be rejected or treated with great caution. This unfortunate attitude has also affected the South African society at large. South Africans still view and experience reality as a unity which is inviolable and indissoluble. Because of this view biblical texts are treated in a similar way: a text is a unity and its meaning can easily be determined by the right method... To a large extent the theological community still operates with a seventeenth-century

1.See the overviews by Du Toit (1993a; 1993b; 1994) and Van Zyl (2000).

2. The studies by Louw $(1973 ; 1982 ; 1992)$ are paradigmatic. An indication of Louw's impact on South African NT scholars is given by Snyman (1999:355 n.4)

3.Famously, by Malherbe (1992), and more recently by Punt (1998); see also the brief comment by West (2000:38). 
hermeneutics, allowing it to oscillate unproblematically between ancient text and present-day context.

(Le Roux 1993:351)

Much of our scholarship can indeed be characterised as 'a-historical and anti-historical-critical' (Le Roux 1993:352). The importance of this characterisation cannot be underestimated. More than twenty years ago, Jeff Guy, an historian, made the following comments about researching South African history; they are probably still valid today, and remarkably relevant, to grasp the setting of South African historical Jesus research:

It is ... difficult in contemporary South Africa to conduct calm historical debate. The divisions of opinion are deep and raw. ... The collapse of historical debate into name-calling, or its cessation altogether, can only work in favour of those who wield authority. The impact of the past on the present is powerful: it can create complacency, but also anger; security in some, but the demand for change in others. This is why so much attention is paid in Southern Africa to the task of obstructing dialogue between the past and the present. It is done in many ways: by trivialising history; by presenting the past as a procession of beleaguered men with good intentions; by holding before a captive, impressionable audience a gallery of heroes suspended in a cloud of myth and racism; or by the straightforward exercise of ... power to suppress information, to control education, and to silence discussion and dissent.

(Guy 1983:x-xi)

The predicaments 'faced by academic historians in South Africa today are rooted in deep-seated political, economic and cultural shifts which have both national and international dimensions' (Nuttal \& Wright 2000:27). In addition, the resistance to earlier political practices also impacted on historical scholarship by black South Africans; not least in rejection: the historical-critical method has been described as 'the hermeneutical yoke of our oppressors' (Mofokeng 1988:39)

\section{DEVELOPMENTS}

Glancing back to the period before the late nineteen-seventies, biblical scholarship can only be characterised as pastoral and focussed on missionary work. It is against this background that the editor of the Journal of Theology for Southern Africa could note in 1978 that there 'appears to be a dearth of New Testament scholarship in our midst, exceptions notwithstanding' (De Gruchy 1978:2). This changed however during the 1980s and 1990s. In 1965 the New Testament Society of South Africa, an academic study group dedicated to, among other aims, promoting New Testament scholarship in South Africa, was founded. From rather small beginnings, the Society developed into a strong, multidisciplinary, ecumenical scholarly community by 1990 . The Society functions through subgroups that organise research projects, including the annual conferences of the Society and international research fellows, and which culminate in the publication of articles in Neotestamentica. ${ }^{5}$ In 1991 the Society started a subgroup dealing with historical Jesus research Initially chaired by Willem Vorster, the subgroup developed into a highly successful project, in a very real sense representing the inauguration of critical historical Jesus research in South Africa. After Vorster's premature death on 10 January 1993, the subgroup managed to continue its activities, organising two of the annual congresses of the Society devoted to the theme of the historical Jesus, in 1995 and 2002, besides several workshops and seminars.

Just as the political change in South Africa was gathering momentum, Willem Vorster contributed a brief essay reflecting

\section{On Tuesday 30 March 1965, at the Potchefstroom University for Christian Higher Education.}

5. Neotestamentica: Journal of the New Testament Society of South Africa, saw its first volume published in 1967; since 1988 two issues per year have been published. Forty-two volumes have been published to date, and it has attracted remarkable international interest See http //www.neotestamentica net.

6.See Draper 1995; Jacobs 1996; Scheffler 1995; Strijdom 1995; Taylor 1999; Van Aarde 1995b; Van Aarde 2000a; Van Eck 1996; Venter 1995, as well as Wanamake 1996. The subgroup is still active. on the relevance of historical Jesus scholarship for the 'new' South Africa:

I do not think that the study of the historical Jesus will afford us answers to all our daily problems in the new South Africa. The one thing it will, however, do is to make us a little more humble in our claims of having answers to difficult questions.

(Vorster 1999:333)

He then notes that:

If Jesus is the answer, we are obliged to say who he was. To do that in an informed manner makes it necessary to do historical inquiry into the origins of faith as well as the "facts" on which these origins were based. Historical study does not provide the basis for faith but it does give answers to the origins of faith. It does not give an answer to the meaning of Jesus, either, but it does explain what significance Christians attach to the "facts".

(Vorster 1999:333)

But even more significantly, he saw the importance of historical Jesus studies as a way, as he described it, 'to come to grips with the current polarisation between traditional and contextual theology', for the sake of the church, Christian faith and the morality of science (Vorster 1999:319). With 'traditional' theology, Vorster had in mind the critical academic discipline pursued within the context of scholarship. This diagnosis of the challenge to South African biblical scholarship is, essentially, the same as the more recent one proposed by LeMarquand (2000:166-167) and West (2000:38): the polarisation between academic and community concerns among various groups interested in the Bible and Christian traditions in South Africa.

Clearly this rift, this (growing) polarisation between academic and communal approaches, needs dealing with, especially given the socio-economic context within which so many are calling for more attention to the New Testament and the relevance of Christian traditions.

This review suggests that some trends in South African historical Jesus research amount to probing possibilities for various alternative avenues to shift theological reflections onto a different plane, and allowing critical discourse to function with distinct connections to our context.

\section{INFLUENTIAL HISTORICAL JESUS STUDIES, 1975-2009}

Among scholars perspectives on the historical Jesus vary not only according to circumstances but especially due to theological interests. In the following discussion my focus on the selected scholars was guided by the influence of their contributions on the shape of the historical Jesus debate in South Africa.

\section{Albert Nolan}

In South Africa, Father Albert Nolan's name is synonymous with Contextual Theology, which found its particular form after the publication of the Kairos Document in September 1985. ${ }^{7}$ As already noted, for most of the twentieth century South African biblical scholarship was driven, by and large, by pastoral concerns, and this is very evident in the work by Nolan, Jesus before Christianity, first published in 1976. Albert Nolan's book is important for a number of reasons. Not only is he the most well-known South African Catholic theologian of the twentieth century, his study of Jesus is probably the most influential theological publication by a South African to date. It has been translated into 10 languages, with more than 200000 copies sold. It was recently (in 2001) reprinted by Orbis Books (USA).

\footnotetext{
7.The Kairos Document was a response to the spiral of violence in the 1980 s, rejecting both 'state theology' and 'church theology'. Nolan played an important role in ing both 'state theology' and 'church theology'. Nolan played an important role in the form lation of this document. The Document found considerable support among (107:108-169) ant 1986, various edilons). For some background see De Gruchy (1997:168-169) and Nolan (1994). In his second book God in South Africa (1988), Nolan made a systematic analysis of the concept contextual theology.
} 
Though informed by European historical-critical work, the explicit concern of this study is to be relevant to the Third World.

My interest is in the man as he was before he became the object of Christian faith. ... We will be searching for the historical truth about Jesus, but even this is not our primary purpose. The method is historical, but the purpose is not.

(Nolan 1976:1)

Nolan (1976:10) emphasises that 'We don't need a biography but we do need to know the historical truth about Jesus'. His book is a powerful challenge to Christians to take their allegiance to the Christian cause to the level of fighting exploitation. For his historical information Nolan relies mostly on the work of Jeremias, Derrett, Gaston, Trocme and Vermes. In Nolan's view, Jesus took two clear, historically recoverable decisions at the beginning of his ministry: (1) by accepting John's baptism he aligned himself with an interpretation of events that saw Israel unconverted and heading for destruction; and (2) as a member of the unoppressed middle class, Jesus chose to identify with the outcasts of Galilean society. According to Nolan, Jesus' work of healing and forgiveness flows from his radical summons to obedience, a counter-cultural direction and a vision of hope. The argument has a straightforward structure. The world of today is facing a collapse of apocalyptic dimension, and organised religion can contribute very little to dealing with it (Nolan 1976:8). There is, however, a parallel between the current world crisis and the historical Jesus:

Jesus of Nazareth faced basically the same problem - even if it was on a much smaller scale. ... With what I would like to call an unparalleled leap of creative imagination, this man saw a way out, and indeed more than a way out - he saw the way to total liberation and fulfilment for mankind.

(Nolan 1976:8)

There is an interesting but brief discussion of the miracles by Jesus (Nolan 1976:21-36). The healing stories are situated in a traditional setting and reference to the ancient worldview is made. To Nolan, Jesus' compassion and trust in God enabled these powerful events, and Jesus' aim was to awaken the same compassion and the same faith in the people around him. Although he avoids a supernaturalistic interpretation of Jesus, Nolan understands Jesus to have been quite unique, 'a much underrated man ... a man of extraordinary independence, immense courage and unparalleled authenticity - a man whose insight defies explanation' (Nolan 1976:117).

Nolan acknowledges that history is a reconstruction, that 'it is the truth of the past in the light of the present' and that to 'imagine that one can have historical objectivity without a perspective is an illusion' (Nolan 1976:4), but he shows no concern with the problem of how to deal with subjectivity. Despite many claims throughout the book, it is not critical historiography. He alleges 'the consistent use of strict historical criticism and methods of research', but the crucial, unresolved problem becomes evident in the second part of that sentence: 'our interest is not the academic pursuit of history for the sake of history' (Nolan 1976:1). Nolan's concern to overcome the divide between (academic) understanding and (practical) relevance becomes an affirmation of that dualism. At the really crucial stages of the presentation critical analysis and historical probing are left behind and reductionist affirmations are employed.

There is no theorising about the traditions or the tradition processes underlying the Gospels nor any analysis of the Jesus materials. All the canonical data is considered to be of the same standard, and for all practical purposes, and no pericope turns out to be unhistorical. Nolan deals, essentially, with the gospels as if they were stenographic reports. Anachronistic concepts abound in the book (e.g., 'middle class'). His exegetical approach is effectively uncritical: the diversity of traditions within the gospels is ignored and there is a frequent cavalier bracketing of 'all serious scholars' to back an opinion presented by Nolan (which inevitably turns out to be unsubstantiated and unsubstantiable).

The importance of Nolan's contribution to historical Jesus research lies not in its critical achievement, but in the manner of using biblical history, which characterises so much of exegetical and biblical research in South Africa. It is remarkable that when compared to other historical Jesus publications designed to be 'relevant to the Church' even though the depictions of Jesus differ (due in part to different arrangements of the material but mostly because of different political agendas of the authors) there are disconcerting similarities with regard to methodology, use of sources, interpretive ploys, style, arguments, attitudes towards the sources, acceptance of conventional pictures about Judaism, the Temple, ancient society and so forth (cf. Craffert 2003b).

Nolan's work encouraged the methodological debate among South African biblical scholars. If his depiction of Jesus is correct, why do so few scholars note it? Does the scriptural end justify the exegetical means? Are there not important ethical and moral issues in cases of methodological indifference and naivety about presuppositions? The success of Nolans's publication probably also detracted from other investigations into the relevance of historical Jesus research, such as that of Nicolson (1990), who fits historical Jesus research into a much wider context of theological and doctrinal reflection.

\section{Andrie B. du Toit}

As professor of New Testament at the University of Pretoria, Andrie du $\mathrm{Toit}^{8}$ has been very influential in New Testament scholarship in South Africa, particularly during the last two decades of the twentieth century. In $1974 \mathrm{Du}$ Toit published an Afrikaans translation of Günther Bornkamm's well-known Jesus von Nazareth. ${ }^{9}$ During the 1970 s he prescribed Bornkamm's book to theological students, justifying its inclusion in the syllabus, with the comment that it represents 'a critical minimum' for 'historically minded scholars'. He met considerable resistance with regard to this, but he succeeded in establishing substantial interest in New Testament scholarship.

The practical/theological motive for Du Toit's interest in Bornkamm's study is that Bornkamm took Jesus' message as being about 'making the reality of God present' (Bornkamm 1960:62). It is relevant to recall that the focus of Bornkamm's study is the message of Jesus. 'No one is any longer in the position to write a life of Jesus' (Bornkamm 1960:13). The history and person of Jesus gains the character of unmediated presence by means of his message about the reality of God, God's kingdom and God's will (Bornkamm 1960:62). In 1980 Du Toit contributed an essay, 'The historical Jesus and the proclaimed Christ of the gospels' (Du Toit 1980; English translation in 1983) to the series of textbooks, Guide to the New Testament. ${ }^{10}$ In this contribution Du Toit's career-long concern that theological issues and matters of faith relating to the New Testament should be based on sound scholarship is quite visible. The essay has an explicit focus on methodology and on the principle issues of the quest for the historical Jesus.

For $\mathrm{Du}$ Toit the 'quest' is one for the 'original Jesus' (Du Toit 1983:258), and the central question is whether there is 'a legitimate connection between [Jesus], his activity, his selfdisclosure in word and action, and the preaching of the gospels concerning him' (Du Toit 1983:257). To answer this question, the search for the original Jesus is theoretically acceptable and

8.Since 1971; he retired in 1996. At the 2006 General Meeting of the Studiorum Novi Testamenti Societas (SNTS), du Toit was elected as President of the SNTS for 2008.

9.Jesus van Nasaret (Genadedal: Verenigde Lutherse Seminarie, 1974), Afrikaans translation of Bornkamm, G Jesus von Nazareth (Stuttgart: Kohlhammer, 1956).

10.A six-volume series designed to provide students with a comprehensive overview of and introduction to all major aspects of New Testament scholarship. The editor is
Andrie du Toit. The series is widely used in South African seminaries and theological faculties, and is available in both Afrikaans and English. 
possibly meaningful. 'The value of this search for the historical Jesus is ... to be found at the level of essential accountability' (Du Toit 1983:263). Three dimensions of accountability are identified: internal (that there is an authentic continuity between the life of Jesus and the proclamation of Christ), external (to facilitate dialogue with non-Christians) and, finally, to better grasp the theological developments within the first-century Church ( $c f$. Du Toit 1983:263-265)

Practically, however, Du Toit is sceptical of the possible success of such a search, and the stumbling block is simply the sui generis nature of the canonical gospels. To understand $\mathrm{Du}$ Toit's resistance, note his emphasis on the ineffable nature of the gospels, which manifests in two related problems. (1) Explicitly acknowledging the influence of Martin Kähler, he highlights the 'nature of the gospels as documents of faith' which renders all attempts 'at compiling from them biographies of Jesus ... futile'. (2) At the same time, this peculiar nature of the gospels excludes 'points of departure that do violence' to it. Such 'other' points of departure reflect 'uncontrolled a priori conceptions' (Du Toit 1983:265) and result in serious methodological flaws. How to deal with any 'a priori conceptions' - let alone identifying unacceptable ones - is not dealt with by him.

Du Toit readily admits 'an undeniable measure of discontinuity regarding Jesus' original words and actions' in the formation of the gospels (Du Toit 1983:266), but emphasises that the nature and compass of this discontinuity is insignificant. He writes of diversions in the Jesus tradition and not changes. A succint overview of the criteria for identifying reliable Jesus material is provided, carefully pointing out the many problems inherent in these criteria. For Du Toit, the Jesus tradition, as reported by the canonical gospel authors, can be regarded as authentic until one proves the opposite. How this could be done is left open which is curious, as Du Toit focuses explicitly on methodological issues. The burden of proof lies with those scholars who argue for non-authenticity (Du Toit 1983:280). There is irony attached to $\mathrm{Du}$ Toit's claim that 'historical Jesus research does have a future' (Du Toit 1983:288). In Du Toit's view the historical Jesus and the kerygmatic Christ are one and the same, and in a very real sense critical historical investigation is unnecessary: what is necessary to know about Jesus, even historically, is already known by those who confess him as the Christ.

It is therefore also understandable that Du Toit takes issue with the conventional denial of the Gospel of John as source for the historical Jesus and the use of what he calls the anti-metaphysical principle of 'analogy'. Criteria such as of dissimilarity or of coherence have extremely limited applicability - being, by and large, inappropriate to the Jesus traditions (Du Toit 1983:282286).The naive resistance to the 'principle of analogy' became crucial to the next generation of South African New Testament scholars. It is precisely consistency and integrity in the application of analogy that enables one to detect Augustan propaganda in Suetonius' report of Octavian's divine birth (Suetonius Augustus 94.4), for instance, or how a community can be critical of claims of witchcraft. ${ }^{11}$ Rather than just boldly affirming a metaphysical commitment, the challenge is the exploration, theorising and critical utilisation of maximal evidence, activating the historical imagination by means of cultural anthropology and social psychology ( $c f$. Botha 2008; Craffert 2002c).

Du Toit, in the words of Van Aarde, 'aimed at creating an atmosphere in which scholars, as members of the believing community, would regard aspects of the Jesus tradition in the canonical gospels as authentic that do not have other analogies in a historiographical sense' (Van Aarde 1993a:402). Du Toit taught his students that method and presuppositions matter, but, even more importantly, he emphasised respect for the text in its context, and detailed attention to the language of the

11.Witchcraft is an inappropriate term for a serious, widespread and highly problematic feature of many South African communities (Hund 2004; Niehaus 2002). It is also an interesting generator of cross-cultural anthropological interpretation of early Christianity. text. These latter principles caused (some of) his students to go different ways.

\section{Willem S. Vorster}

Vorster, director of the Institute for Theological Research at the University of South Africa, 1976-1993, was an erudite New Testament scholar, deeply committed to establishing a critical tradition in South African biblical scholarship. In a sense he took Du Toit's rejection of fundamentalism and a 'pre-critical' stance (Du Toit 1983:269, 276) far more seriously than his Doktorvater himself. In one of his earlier publications, Vorster drew attention to the complexities surrounding the role of the historical Jesus in the origins of Christianity, concluding that:

... to ask the question whether Jesus was a Christian is in a certain sense an anachronism but it is also a very important aspect of understanding Christianity in its origins. Jesus was a Jew and not a Christian in the kerygma-sense of the word. On the other hand he was a Christian in the sense of the one who started giving a Christian colouring to Jewish thought in a Jewish setting.

(Vorster 1981:48)

These themes would characterise Vorster's growing interest in the historical Jesus. In 1991 he published two articles: 'Jesus the Galilean' and 'Jesus: Eschatological prophet and/or wisdom teacher?' (Vorster 1999:285-318; the articles were first published in Hervormde Teologiese Studies 47, 1991). In the first essay Vorster discusses the question, 'why there seemingly is confusion, if not total chaos, in the answers given to the question of who Jesus was' (Vorster 1999:286). He argues the importance of understanding Jesus within the geographical area in which he operated and the historical circumstances under which he lived. In the second essay Vorster shows that there are two plausible answers to the question of who Jesus was, and contends that it is not necessary to put the two images of Jesus as prophet and as teacher in opposition.

The teaching of Jesus was radical. It was not revolutionary in the modern sense of the word. He was mistaken by the Romans as a messianic pretender and a danger to the Empire, and was killed on the cross. After his death he was put into many religious roles because of his significance for his followers. Before his death he enabled people, by his teaching, to cope with life and to pursue a lifestyle in accordance with his perception of the will of God.

(Vorster 1999:317)

During this period Vorster also initiated a research project on presuppositions and methodology in New Testamentscholarship. Part of this, in collaboration with myself, was submitted in a report to the then Human Sciences Research Council..$^{12}$ In this study the underlying theme is the Jewishness of Jesus. The choice to focus on Jesus' Jewishness was not without reason; if the New Testament is to be read as relevant and important to South African issues, the conviction is that the New Testament must first speak about its own issues: Jew-Gentile relations, identity and faith, and so forth. It is from an analysis of issues such as the identity and self-definition of Jesus and his earliest followers that current concerns should be related to scriptural statements and the historical Jesus. Furthermore, it is from such analyses that it was recognised that 'Jewishness' was an underestimated and neglected problem in historical Jesus research (Botha 1994). Besides the question of whether the historical Jesus should be seen as either an eschatological prophet or a wisdom teacher the epistemology of historical research and the presuppositions regarding the quest attracted Vorster's attention.

In one's encounter with antiquity ... there is a lack of sources, and it is difficult to construct ancient views on reality concepts and experience. There is no way in which it is possible to make a reconstruction of Palestine in the times of Jesus - as with any other historical phenomenon. It is very difficult, if not impossible - on theoretical grounds - to re-enact the past, let alone the life, deeds and words of a religious figure who lived two thousand years ago. The evidence is clouded by the paucity and the fortuitousness of the data and often also by the history of interpretation.... [T]

12.See Vorster \& Botha 1992. The HSRC decided not to publish the manuscript, in view of preference to Reconstruction and Development Programme (RDP) projects (correspondence dated 18 May 1995). 
he relationship between the subject (historian) and the object of investigation in the past (past phenomena such as persons, actions and people's words) is complicated. It can no longer be seen as a 'knowing subject' here who investigates a 'knowable object' out there in the sense of observing reality. It is no longer possible to think that the task of the historian is to reconstruct the past objectively in terms of causes and effects. No historical interpretation can claim to be a reflection of what really happened in the past. Historians make constructions of the past according to their interaction with the evidence, in the light of their theories and hypotheses. These constructions are guided by the criteria of probability and plausibility. By their very nature historical judgements are not objective descriptions of what really happened. They are socially conditioned constructions of the past (...). They are products of the mind, built on a great variety of presuppositions and perceptions.

(Vorster, in Vorster \& Botha 1992:2-3, 5)

Vorster (1990) also reflected on the use of metaphors to describe and understand Jesus' identity and in a perceptive study he addressed the relevance of historical Jesus research for the 'new' South Africa (i.e., post 1992 South Africa; Vorster 1994). Vorster concluded with a challenge to both New Testament scholars and theologians, affirming the need for historical research about Jesus and the implications of the historical study of Jesus for Christian theology (Vorster 1994:625-631). Specifically, there is 'a need for theologians who relate their theology to the teaching of Jesus and to the portrayals of Jesus in the New Testament to take seriously the results obtained by historians in order to come to grips with the nature of their own theology.' He felt that the use of New Testament phrases and images as if they were historical as such amounted to abuse:

The mistake of traditional theology is being unaware of the importance and influence of the modern theologian's context in theological reflection. The mistake of Black theology is that the importance of the historical context of Jesus and the distance between then and now are disregarded. ${ }^{13}$

(Vorster 1994:631)

Theimpact of Vorster's work, particularly with regard to historical Jesus research, comes from other aspects of his research. In many ways, Vorster was a 'first' in South African biblical scholarship, particularly in South African New Testament study. He was the first to actively engage critical methods, and he forced those in conversation with him (and obviously his students) to grapple with critical methods on a more profound level. In the case of Vorster, one did not simply reject a method because one did not like the results. Formgeschichte is a very problematic venture, but one can no longer analyse the gospels as if Formgeschichte does not exist. Redaction criticism, in terms of establishing textual communication, was a failure, but it is still the best explanation for many characteristics of the data about Jesus according to Vorster (1980; 1982a; 1982b; 1983; 1989). Vorster forced us to sharpen our methodological awareness: to move beyond a mere rejection or an uncritical repetition of conventional analytical tools. This influence can especially be seen in the growing sophistication among South African scholars' understanding of the early Jesus traditions. His concern with the role of presuppositions in research prompted many further investigations, specifically with regard to historical Jesus study (Arendse 1997; Geyser 1999; 2000; Liebenberg 1997).

In his 1990 address to the Relevance of Theology conference held in Stellenbosch, Vorster made two perceptive comments identifying central problems in most South African discussions of the historical Jesus. He criticised conventional engagement with the historical Jesus among South African scholars which

refers to critical scholars but never takes seriously the tremendous historical problems involved in describing the life of Jesus, or even any of the events in the life of Jesus as they are

13.Vorster 1994:631, referring to the work of Black theologians such as Frank Chikane. Vorster had a very strong commitment to the cause of black liberation (his politics played no small part in the resistance to his scholarship in South Africa); yet he was adamant that proper method in the exegesis of texts should never be neglected, even if the Bible is involved (Vorster 1984). presented almost at face value in the New Testament. There seems to be no understanding of the history of traditions concerning Jesus, and all the material is harmonised into an eschatology of the salvation acts of Jesus.

(Vorster 1994:627)

Resistance to this kind of publication, which claims to be historical, became characteristic of scholars working in the wake of Vorster. Vorster also said: 'Too often the world of Jesus is seen in compartments and he is viewed only in a religious or a political role. That is a mistake' (Vorster 1994:623). The effort to work more holistically, more comprehensively, and more inter- and multidisciplinary would in fact become the hallmark of the current generation studying the historical Jesus. Vorster stimulated others to engage the context of the New Testament, and the growth of interest into the first-century Mediterranean world among most current South African New Testament scholars can be attributed to his influence.

\section{Andries G. van Aarde}

A different line of development after Du Toit can be seen in the work of the prolific Andries van Aarde (currently an honorary professor at the Faculty of Theology, University of Pretoria; until 2006 he was professor in the Department of New Testament Science). As is the case with Du Toit and Vorster, Van Aarde takes his point of departure in explicit methodological reflection. To Van Aarde, historical Jesus research demands a threedimensional textual investigation in engaged hermeneutics; the literary, social scientific and theological all have to be taken into account. Specifically, his aim is to develop an interaction between literary critical and social-scientific approaches. Van Aarde sees the scientific success of the historical endeavour in the extent that one manages to avoid ethnocentric descriptions on the one hand, and reductionism on the other. Although multifaceted, Van Aarde's historical Jesus research revolves around a central theme, namely Jesus as a social outcast. This, incidentally, is the title of an early lecture of his (published in 1988), but is also evident in his 1992 study 'The Evangelium Infantium, the abandonment of children and the infancy narrative in Matthew 1 and 2 in social scientific perspective' (Van Aarde 1992), and developed through a number of studies.

In the process of developing his portrayal of Jesus as a social outcast much is done to avoid facile application of historical information to contemporary issues. It is one of Van Aarde's strong points, this emphasis on the 'distance' between our concepts and issues and the world of the first century. Persons and social institutions should not anachronistically be treated from modern economical and political perspectives. Initially, Van Aarde referred to the earthly Jesus (as the subject matter of the quest for the historical Jesus), but later adopted terms such as the 'cause of Jesus' (die Sache Jesu) and 'a historical construct of Jesus' whole life' (see, e.g., Van Aarde 1995a; 2001a).

In addition, and quite in line with South African biblical scholarship, is his concern to show the relevance and importance of the historical Jesus to theologising and practical church matters (Van Aarde 1994; 1995a; 1997; 2000b; 2003). For Van Aarde, the Jesus of history keeps us in touch with the radicality of Jesus' emancipatory living - a dimension that can easily be lost as tradition develops. Categories, such as the 'kerygmatic Christ', have lost explanatory power in the current religious age (Van Aarde 1997). The development of theological ideas and church traditions needs always to be measured against the historical words and deeds of Jesus (Van Aarde 1993b:949). To Van Aarde, holding onto the importance of the dialectic between our understanding of the historical Jesus and our reading of ancient texts as the classical witnesses to New Testament Christianity is not only desirable but also essential for engaged hermeneutics in general and for being an engaged Christian today (Van Aarde 1993b:949-950). 
His most interesting contribution thus far is probably his exploration of the Joseph-narratives and, as he describes it, Jesus' fatherlessness. A number of exploratory essays culminated in his recent monograph, Fatherless in Galilee: Jesus as child of God (Van Aarde 2001b). Van Aarde presents a wide-ranging argument to demonstrate the historical probability that Joseph, the father of Jesus, should be regarded as a legendary figure. The narratives present in the gospel traditions are modelled after the patriarch in the Old Testament. It is crucial, according to Van Aarde, that the figure of Joseph is absent from Paul, Mark, Q, and the Gospel of Thomas. The standard explanation for Joseph's absence from these sources claims that he must have died prior to Jesus' ministry, but Van Aarde argues that no known father played a role in the life of the historical Jesus. While Joseph is named in Matthew, Luke and John, he was a legendary figure added to the gospel traditions sometime after Easter; early Christians answered Pharisaic charges concerning Jesus' fatherlessness by creating a father named Joseph, who stands in the succession of Joseph the son of Jacob who was known for his forgiveness This early Christian action represents the fifth in a seven-link 'Joseph trajectory' that began with the Genesis narrative about the patriarch Joseph and continued with the prophetic traditions concerning the descendants of Joseph's children, the defensive Judean reaction, the historical Jesus, the addition of Joseph to the gospel traditions, and two stages of consequent Christian embellishments of these traditions.

In the peasant society of Jesus' world, the family revolved around the father. In first-century Mediterranean culture, fatherlessness led to marginalisation. The historical Jesus was a 'fatherless' child. Assuming that the boy Jesus would have experienced the pain inflicted on such children by first-century Galilean society, Van Aarde maintains that this factor explains various aspects of Jesus' ministry, such as his identification of God as his heavenly Father, his non-patriarchal ethos, and his compassion for women, children, the sick, and other powerless people. Van Aarde makes ample use of social-scientific research to provide depth to the meagre details that we possess. Among others, he employs the status envy hypothesis to argue that the young Jesus' status as a fatherless child would have caused him to envy the status provided by a father. This, Van Aarde suggests, led to the adult Jesus' antipatriarchal behaviour and to the phenomenon of the adult Jesus often acting in a womanlike manner.

The central contribution of this book is the construction of a possible link between the painful events experienced by the boy Jesus (ostracism due to fatherlessness) and various distinguishing marks of his ministry (such as his trust in his heavenly Father and his compassion for other outsiders).

Jesus ... did not use the metaphor of father as the way to God, but that of child. Those not childlike could not experience the presence of God. Even more radical than this is that Jesus did not use the child who had been legitimized by the father as symbol. He pointed to an illegitimate child as a symbol of those who belonged to the realm of God.

(Van Aarde 2001b:197)

Historical Jesus research is fundamental to the credibility of Christianity in that Christianity is not a 'book religion' but represents belief patterns witnessed in the New Testament and is modelled on the words and deeds of Jesus of Nazareth, experienced and confessed by Christians as child of God.

(Van Aarde 2001b:203)

We live in a world inexorably changed, with the church as institution and its canon becoming outdated, yet, precisely because of these historical processes and despite the terminological problems, the relationship between the 'historical Jesus' and the 'kerygmatic Christ' will have to be asked and answered over and over again .... The challenge is to find a meaningful answer to this question for the immediate present (Van Aarde 2003:550). Such answers presume the plausibility of a continuity or a discontinuity existing between the Jesus of history and the Jesus of faith, and require that historical-critical research be complemented with social-scientific inquiry (Van Aarde 2002).
The integration of social-scientific models into New Testament scholarship in South Africa is becoming quite widespread, but it is especially prominent among those interested in the historical Jesus. Johan Strijdom (Religious Studies, University of South Africa), who studied with Van Aarde, takes on Stevan Davies' analysis of Jesus' baptism (Davies 1995). Strijdom evaluates Davies' presentation in terms of his database of sources, his arguments for authenticity, and his psychological explanation of this crucial event in Jesus' life. Strijdom concludes that Davies' psychological analysis should be supplemented with a consideration of social values if we wish to understand the historical Jesus better (Strijdom 1998). Strijdom has also produced an interesting critique of John Dominic Crossan's understanding of history and fiction in ancient sources (Strijdom 2003).

Ernest van Eck (Department of New Testament Science, University of Pretoria) shows the interesting possibilities for the historical Jesus quest when he proposes an interpretation of Jesus' baptism as a ritual of status transformation (Van Eck 1996). This transformation, he suggests, was fundamental to Jesus' understanding of God, and indicates that Jesus probably was a 'spirit person' (Van Eck 1996:212-213). Disappointingly, in his study on Jesus' resurrection he avoids social-scientific perspectives (Van Eck 2004). He develops a stimulating reading of Gospel of Thomas 65(/Mk 12:1-12) construing a setting by means of social-scientific research dealing with honour and status. He points out the possible continuity of this parable with the historical Jesus:

Jesus, in GThom 65, thus not only challenges status as the protection of honor, but violence too. Resorting to status does not necessarily lead to honor, and similarly the use of violence does not achieve honor either. On the contrary, what brings honor is to answer violence with mildness.

(Van Eck 2007:934)

Charles Wanamaker (University of Cape Town) argues that a cross-cultural approach - which is obviously a variant of socialscientific analysis - is more fruitful. In an interesting article Wanamaker (after due consideration of methodology, of course), discusses how ancestor beliefs of contemporary South Africans can be used to articulate a link between Jesus and African Christians (Wanamaker 1997). But when it comes to culturalanthropological exploration of New Testament issues, we must turn to the work of Pieter Craffert.

\section{Pieter F. Craffert}

Craffert is professor in the Department of New Testament and Early Christian Studies at the University of South Africa, teaching Biblical Archaeology. As a student of Vorster, he too takes an explicit methodological and meta-theoretical approach to his research topics, and is committed to the cross-cultural approach to understanding the earliest Christian documents and history. He has explained his approach, which he describes as 'historicalanthropological', in a number of important articles (Craffert 1992; 1996a; 1996b; 2002b; 2003a; Craffert \& Botha 2005). In search of the 'living reality' of others he wants to go a step further than the 'content oriented approach', which he identifies in other proposals. Consequently, Craffert delineates his programme as different from conventional quests, arguing that his approach is more realistic in terms of historiography and also more acceptable in the terms of philosophical questions, but most of all, it is a realistic management of ethnocentrism and subjectivity. He is not in search of the 'real' Jesus, nor the 'original' Jesus, but wants to establish Jesus' identity as a historical figure. He adopts an interpretive style rather than a method (or combination of methods). This style is an imitation of a cultural dialogue. What Craffert wants to achieve is the identification of the social type Jesus belonged to and which correlates with an interpretation of all the Jesus material (and not just a reduced version of it) within a valid cultural-anthropological context. Jesus' personal profile, the historical setting and the stories about him should all be considered as 'configurations of each other' (Craffert 2002b:441-445). 
One of the reasons why Craffert is critical of the technique of criteria of authenticity to determine reliable Jesus material is the research on the complexities of ancient literacy, orality, tradition and communication (Craffert 1995:304; 1999:321, n 1; 2002b:453-456). Essentially, and particularly in terms of the search for the earliest layers of Jesus material, the point is that a multidisciplinary critique of conventional Traditionsgeschichte in terms of what we know about oral traditions and oral history undermines the premises on which the identification of authentic Jesus material rests. That is, once one realises that the 'dominant paradigm of linearity' in most reconstructions of the traditions underlying the Gospels is mistaken, one must find alternatives to conceptualising the synoptic problem generally and specifically conventional ideas about criteria of reliability. ${ }^{14}$ If it is true that scholars have not really grasped what the oral foundations of the synoptic traditions entail, their reconstruction of them must be defective. This is something that Jonathan Draper (professor in New Testament at the University of KwaZulu-Natal) also emphasises; he has explored several of the implications (Draper $1996 ; 1999){ }^{15}$

Craffert has also developed a serious critique of the Jesus Seminar, which practices a positivistic modernist history and falls victim to the ethnocentric fallacy in various ways. He is also critical of the Third Questers (the more 'traditional' historical Jesus researchers, such as Thomas Wright and Marcus Borg - see, e.g., Craffert 1995:106-109; 2001:10-19; 2002b:456-463; 2003a). Once more, one can notice aspects of our context in his emphatic plea for a culturally sensitive approach to ancient texts. Interpretive concepts are culturally determined, and scholars tend to assume normativeness about their own, especially with regard to historical persons who cannot respond to our appropriations of them. The historical Jesus that emerges in Craffert's research is along the lines of a charismatic prophet, an exorcist and a healer, but Craffert is distinctly dissatisfied with these terms as they have become laden with Christian theological ideas (thus a-historicising the discussion), but more importantly, in terms of cultural types, they are simply insufficiently descriptive of all the data about Jesus that we possess.

He is emphasising that precision in the use of interpretive categories is necessary: a prophetic activity is not the same as a prophet, an exorcist is a distinct social type, a stringing together of terms serves only to concretise selective and contradictive characteristics into traits and facts. Craffert argues that the point of historical Jesus research is not merely to determine whether something happened or not, whether this or that is true or not, but to determine the meaning of what was told: how and why did these claims and descriptions became part of Jesus' biography. Craffert suggests the use of the 'shamanic complex' as a social type model to understand the historical Jesus.

While it should be obvious that the suggestion of the shamanic complex has many affinities with Vermes' holy man, Borg's spirit person and Davies's spirit possessed prophet/healer ... the shaman as social type differs from these. None of these social types covers the same pattern or contains the same combination of features and functions associated with the shamanic complex... [which] brings together the various altered states of consciousness experiences (spirit possession, visions, trances) with a combination of social functions which are regularly ascribed to Jesus. ... With the shamanic model many of Jesus' ascribed activities can be seen as interconnected to a basic pattern.

(Craffert 1999:339-341)

14.See, especially, DeConick (2008) and Kelber (2008). Wide ranging and general aspects related to these issues are covered by Assmann 2006; Botha 1990; 1991; 1993; 1998; 2005a; Byrskog 2000; Dunn 2003; Foley 2006; Hearon 2004; Mournet 2005.

15.With the rejection of the 'original form' concept, most of the current reconstruction of the rejection of the 'original form' concept, most of the current reconstruction probably the gospel authors themselves heard $Q$ and the other sayings traditions, one cannot possibly apply the concept of an original version in reconstructing them, one cannot possibly apply the concept of an original version in reconstructing them.
Curiously, even scholars familiar with research on orality and memory remain Curiously, even scholars familiar with research on orality and memory remain
committed to the conventional Q-hypothesis.
This exploration has culminated in a monograph (Craffert 2008b). Historical Jesus research 'remains trapped in the historiographical framework from which it emerged more than a hundred and fifty years ago and is limited to the positivistpostmodern historiographical continuum' (Craffert 2008b:231). In contrast, Craffert offers two distinct advances to initiate a paradigm change. Negatively, one based on developments in historiographical discourse, a critique of the idea that a historical figure could not have been like the Gospel portrayals and consequently that the Gospels have developed in a linear and layered fashion from the authentic kernels to the elaborated literary constructions as they are known today. The social type identified in such constructions remains a talking-head who spoke some authentic words and a disconnected actor who performed some public deeds, depending on the interpretive strategy, either within the setting of first-century Judaism or that of the Roman Imperial Rule. The other, constructively, engages cultural anthropology in its interpretive mode to acknowledge multiple cultural realities and the existence of other forms of life as constitutive of the historical subject and the historical record. He offers a framework for a cultural sensitive understanding of Jesus of Nazareth as social personage embedded in his social system and world-view.

In an article Craffert discusses the variety of images of Jesus found in African Christianity (Craffert 2002a). The main trends in these depictions are the quest for what Jesus can do for Africans and the inculturation of Jesus in African images. Although historical Jesus research receives very little attention in African scholarship, Craffert argues that attempts at historical understanding of Jesus within his particular cultural setting should discover many clues from the study of religious specialists in African traditional religions. From such an approach, Jesus as an historical figure can not only be described as similar to typical religious practitioners in various African traditional religions, but new avenues for inter-religious dialogue in Africa are provided.

\section{LIGHTING A CANDLE ...}

As elsewhere, South African New Testament scholars conduct their historical Jesus research in a setting of neo-liberal technologised capitalism and the consequent McDonaldisation of religion (Botha 2006). Various interest groups promote 'plain talk' about Jesus, making him an objective entity 'present-athand', which can idly be used for their own purpose (and the process can vividly be illustrated by the history of the Bible in South Africa). Jesus is 'mythologised' into a manipulable reservoir of legitimations. Such practices have lulled many into a passive attitude where seriousness about the historical Jesus has become a sign of unbelief. Critical thinking is an indispensable way of putting Jesus in a historical perspective and to deliver Jesus from the ideologised distortions of perceiving the world, but also to free thinking about Jesus to consider what he did contribute to the understanding of our present-day miseries. History, in the words of Jurie le Roux, deals with life, the daily existence of ordinary people, and historical investigation illuminates the many facets of our shared humanity; it is a way of relating to life and its challenges; it is a way of discovering life's meaning by understanding the lives of others; it is a way of understanding humanity's hopes and fears; it is providing some direction and orientation in this life. Our historical endeavours are thus a very human, personal and even fragile undertaking (Le Roux 2008).

Theologically speaking, this is what historical Jesus researchers in South Africa have been working at (since Willem Vorster's impact): to show that the 'real' Jesus is someone other than what he has been made into by various ideological stances. As Craffert puts it, to responsibly describe something 'of the life of a historical figure that evades historical thinking' (Craffert 2008b:233). Recall the wider context of theological scholarship in South Africa and the characteristic emphasis on just the (biblical) text - initially the grammatico-literal approach, superseded by 
structural analysis. Structural analysis (in its South African form) works with a distinct phenomenological reduction: a bracketing of the extra-linguistic world. The single sign is sufficient. All that is needed is the correct method and the correct execution of the different steps and soon the true sense of a text will be determined. In 1994 Ferdinand Deist laid a very serious charge against South African biblical scholarship, namely that naive realism and positivist rationalism determine the thought system (denksisteem) of South African Bible scholars (Deist 1994:341-342, 347).

Deist shows how the many quests for justifying textual (Scriptural) exclusivity as basis for theology and religion are just attempts at finding new ways of expressing naive groundings for certainty, rationalisations for residing in our own 'cultural gardens', thereby remaining socially blind and irrelevant (Deist 1994:355-357, 362-364). Need we more encouragement for serious critical reflection? Historical Jesus research is a means of resistance to such phenomenological reduction. Note that the extending of interest to the historical Jesus was not simply a return to traditional historical critical methods. These scholars also asked what it means to adopt a historical perspective. A distinct multidisciplinary approach that strives to achieve a fuller, realistic and critically reliable involvement with the texts and artifacts from the past can be indicated. Indeed, among the responses to Craffert's Shaman those by South African scholars emphasise theoretical and epistemological aspects, focussing on the nature of history and historiographical investigation (Botha 2008; Dijkhuizen 2008; Le Roux 2008; Van Aarde 2008; Vorster 2008). Despite considerable praise, the level of sophistication demanded is breathtaking. But such is the bar that South African historical Jesus researchers have set to overcome the limitations within which current historical Jesus research commenced some two centuries ago as a modernist challenge to stereotypical and orthodox portrayals of Jesus, and to break the shackles of conventionalised and modernist historiography in which historical Jesus research emerged ( $c f$. Craffert 2008a).

South African historical Jesus research is refusing to allow theology a unique 'method' and insists that knowledge of Jesus can only be proper knowledge when measured like any other manifestations of knowledge - with disciplined, rigorous and critical application of scientific principles. 'Relevance was never far from the scholars grappling with the historical Jesus, and again a distinct development can be discerned'. Contemporary questions are integrated into the research, but in a scientific, critically aware manner:

It is generally recognized that all scholars are affected by their contexts; it is not so generally recognized that the contexts (social, political, religious) from which we read may actually aid us in understanding the history behind the text. Biases may blind us; biases also have heuristic value.

(LeMarquand 1997:161)

This is quite precisely what can be detected in South African historical Jesus studies - sometimes quite directly, sometimes obliquely or evocatively - but with a profound commitment to substantiate the role of such heuristic biases.There is a clear praxis of not just how we look, but who and from where we are looking. The various possibilities presented, expressing Jesus' meaning in historical, real terms, create scope for rethinking, reconceptualisation and re-appropriation of Christian traditions

It is important to realise that the questions raised by historical Jesus investigation is not just about having misunderstood the mythical and theological associations that the historical Jesus accrued. The contributions of those reviewed here lies in raising awareness of the necessity to question one's participation in theologising and mythmaking. The claim is that historical understanding leads to historical change. In other words, once some understanding has been gained - that is, to grasp a historical 'fact' in the sense of embedded event - you change, you are modified. This change is the equivalent of a step forward in the process of not only self-liberation, but a critical contribution to one's community's self-reflection. Despite many differences and disagreements, an obligation to transform and reconstruct our ideological narratives shines through these discussions. The tacit proposal is that we should move beyond a naive quest for the truth of a tradition towards a struggle over what makes certain traditions worth caring about and what kind of society to strive for - hence, among other efforts, the appropriateness of a rhetorical critique of Jesus scholarship (cf. Vorster 2008).

Among ourselves the most pressing challenge at hand is further clarification of the interaction of theology and critical history, as can be seen in the questions raised by Dijkhuizen (2008), Le Roux (2008) and Van Aarde (2008). Scholars like Botha (2005b), Van Aarde (1999; 2004) and Craffert (2006; 2007) emphasise that a deeper understanding of reality, with a more holistic and complexifying approach to controversies, is unavoidable. These perspectives are crucial when we consider the prominent characteristics of Christian identity in South Africa, and the relative lack of success (or, rather, the lack of effective influence) of historical Jesus research. The relative failure to effect change in the dominance of the naive realism paradigm in religious and theologicaldiscourse are related to various societal characteristics. There is, for instance, still a deep-seated opposition to science (if not outright fear) in our communities, as can be seen in the persistent poor results of scientific subjects in our schools. And the resistance to historical understanding is precisely part of the academic scene because it is so entrenched in society.

Generally speaking, South African Christians still perceive reason and faith as opposites. Our history has bequeathed to us an authoritarian value system, which manifests in our communities maintaining an unshakeable belief in absolute and final truth. To all of these issues one can but affirm that much should be contributed. 'We believe that we pursue not certainty but understanding, and do so with the knowledge that our interpretations too will prove inadequate. For all is interpretation' (Tracy 1989:463).

\section{CONCLUSION}

South Africa is a comparatively young democracy - a developing country with rather limited resources. Even though our country has seen remarkable changes during the last decade and a half, we are facing immense challenges, not the least of which is the upkeep and further development of academic and intellectual vocations. In a myriad of ways the heritage of our past must be dealt with - and is being acknowledged in historical Jesus research, as should be evident from this review. South African historical Jesus research is very strong on methodological issues, and is remarkably aware of the adage that what is said, is said by someone in a specific context, at a specific time and for a specific audience. One often encounters opposition when arguing for a more critical theology. This is strange, because, though there may be doubt whether all humans are religious, what cannot be doubted is that all humans can think - all of us can be (and are, when need be) critical. In order to become more humane, more devoted to God, we need to apply our minds... Truth depends upon the cultivation of the intellectual virtues: doubt, scepticism, self-criticism. Similarly, religious truth does not lie in any final positions, the possession of fixed deposits of truths, but in the direction of movement given by the lengthy trail of broken images and abandoned illusions. Part of a critical hermeneutic is the role of conversation (or dialogue). What needs to be emphasised - even more than the imperative to do inter- and multidisciplinary research - is conversation among theological pursuits. It is worrying that South African theologians acknowledge the importance of hermeneutics, but clearly the reality is very much one of every one sitting under one's own vine or fig tree and confining oneself to that little shade.

Much theological reflection is done as if biblical scholarship does not exist; of more concern is the terrifyingly eclectic and 
abusive use of biblical 'research' for the sake of authoritative convenience (and, it must be admitted, some biblical scholars themselves contribute to this practice). What furthermore must be emphasised is that biblical scholars, as Dirkie Smit has pointed out, tend to do their work as if other theological disciplines do not exist (he has in mind specifically Systematics and Ethics) and often do not intend to communicate with other disciplines (Smit 1996). We dare not neglect our conversations. After all, we only have ... each other, and we must 'translate' our positions to one another. 'And no labels of [anyone's] minting ... should becloud our common ethical and religious-theological responsibility to converse and translate' (Tracy 1985:472).

\section{REFERENCES}

Arendse, R.A., 1997, 'Shifting boundaries in historical Jesus research? Some critical reflections on paradigms and images of Jesus in current North American scholarship', Scriptura $63,435-449$.

Assmann, J., 2006, 'Form as a mnemonic device: Cultural texts and cultural memory', in R.A. Horsley, J.A. Draper \& J.M. Foley (eds.), Performing the gospel: Orality, memory, and Mark, pp. 67-82, Fortress Press, Minneapolis.

Bornkamm, G., 1960, Jesus of Nazareth, transl. I. McLuskey \& F. McLuskey, Hodder \& Stoughton, London.

Botha, P.J.J., 1990, 'The task of understanding the Gospel traditions: Werner Kelber's contribution to New Testament research', HTS Teologiese Studies/Theological Studies 46(1\&2), 47-70.

Botha, P.J.J., 1991, 'Mark's story as oral traditional literature: Rethinking the transmission of some traditions about Jesus', HTS Teologiese Studies/Theological Studies 47(2), 304-331.

Botha, P.J.J., 1993, 'The social dynamics of the early transmission of the Jesus tradition', Neotestamentica 27(2), 205-231.

Botha, P.J.J., 1994, 'Jesus the Jew: Some reflections on current investigations', Religion $\mathcal{E}$ Theology 1(2), 185-209.

Botha, P.J.J., 1998, 'Rethinking the oral-written divide in Gospel criticism: The Jesus traditions in the light of gossip research', Voices: A Journal for Oral Studies 1, 28-58.

Botha, P.J.J., 2005a, 'New Testament texts in the context of reading practices of the Roman Period: The role of memory and performance', Scriptura 90, 621-640.

Botha, P.J.J., 2005b, 'Theology, rationality and truth-claims: Metatheoretical reflections on self-deception', Religion $\mathcal{E}$ Theology 12(2), 97-128.

Botha, P.J.J., 2006, 'Secular spirituality as virtue ethics: Actualising the Judeo-Christian tradition today', in C.W. Du Toit \& C.P. Mayson (eds.), Secular spirituality as a contextual critique of religion, pp. 95-126, University of South Africa (RITR), Pretoria.

Botha, P.J.J., 2008, 'Cultural-anthropological history and the Jesus traditions', Theologia Viatorum 32(2), 92-141.

Byrskog, S., 2000, Story as history - history as story: The gospel tradition in the context of ancient oral history, Mohr Siebeck, Tübingen.

Craffert, P.F., 1992, 'More on models and muddles in the social-scientific interpretation of the New Testament: The sociological fallacy reconsidered', Neotestamentica 26(1), 217-239.

Craffert, P.F., 1995, 'Wie sê jy is Jesus? Die dialektiek tussen Christus vandag en Jesus van ouds', Religion $\mathcal{E}$ Theology 2(3), 298-312.

Craffert, P.F., 1996a, 'On New Testament interpretation and ethnocentrism', in M.G. Brett (ed.), Ethnicity and the Bible, pp. 449-468, Brill, Leiden.

Craffert, P.F., 1996b, 'Relationships between social-scientific, literary, and rhetorical interpretations of texts', Biblical Theology Bulletin 26(1), 45-55.

Craffert, P.F., 1999, 'Jesus and the shamanic complex: First steps in utilising a social type model', Neotestamentica 33(2), 321342.

Craffert, P.F., 2001, 'Vernuwing in historiese Jesus-navorsing', Verbum et Ecclesia 22(1), 1-29.
Craffert, P.F., 2002a, 'Appropriating historical Jesus research in Africa', Religion $\mathcal{E}$ Theology 9(3/4), 199-224.

Craffert, P.F., 2002b, 'Historical-anthropological Jesus research: The status of authentic pictures beyond authentic material', HTS Teologiese Studies/Theological Studies 58(2), 440-471.

Craffert, P.F., 2002c, "“Seeing" a body into being: Reflections on scholarly interpretations of the nature and reality of Jesus' resurrected body', Religion $\mathcal{E}$ Theology 9(1/2), 89-107.

Craffert, P.F., 2003a, 'Crossan's historical Jesus as healer, exorcist and miracle worker', Religion $\mathcal{E}$ Theology 10(3), 243-266.

Craffert, P.F., 2003b, 'Mapping current South African Jesus research: The Schweitzerstrasse, the Wredebahn and cultural bundubashing', Religion E Theology 10(3), 339-377.

Craffert, P.F., 2006, 'Multiple realities and historiography: Rethinking historical Jesus research', in C. Breytenbrach, J.C. Thom \& J. Punt (eds.), The New Testament interpreted: Essays in honour of Bernard C Lategan, pp. 87-116, Brill, Leiden.

Craffert, P.F., 2007, 'New Testament studies - preventing or promoting a humane society?' Religion $\mathcal{E}$ Theology 14, 161205.

Craffert, P.F., 2008a, 'Anthropological-historical Jesus research: Reflections from the inside', Theologia Viatorum 32(2), 219273.

Craffert, P.F., 2008b, The life of a Galilean shaman: Jesus of Nazareth in anthropological-historical perspective, Cascade Books, Eugene.

Craffert, P.F. \& Botha, P.J.J., 2005, 'Why Jesus could walk on the sea but he could not read and write: Reflections on historicity and interpretation in historical Jesus research', Neotestamentica 39(1), 5-38.

Davies, S.L., 1995, Jesus the healer: Possession, trance and the origins of Christianity, SCM, London.

DeConick, A.D., 2008, 'Human memory and the sayings of Jesus: Contemporary experimental exercises in the transmission of Jesus traditions', in T. Thatcher (ed.), Jesus, the voice, and the text: Beyond the oral and the written gospel, pp. 135-180, Baylor University Press, Waco.

De Gruchy, J.W., 1978, 'Editorial', Journal of Theology for Southern Africa 25, 2.

De Gruchy, J.W., 1997, 'Grappling with a colonial heritage: The English-speaking churches under imperialism and apartheid', in R. Elphick \& R. Davenport (eds.), Christianity in South Africa: A political, social and cultural history, pp. 155172, David Philip, Cape Town.

Deist, F.E., 1994, Ervaring, rede en metode in Skrifuitleg: 'n Wetenskapshistoriese ondersoek na Skrifuitleg in die Ned. Geref. Kerk 1840-1990, Human Sciences Research Council, Pretoria.

Dijkhuizen, P., 2008, 'Construing texts in their pastness and otherness: An investigation into the aim of historical Jesus research within the paradigm of anthropological historiography', Theologia Viatorum 32(2), 49-91.

Draper, J.A., 1995, 'Wandering radicalism or purposeful activity? Jesus and the sending of the messengers in Mark 6:6-56', Neotestamentica 29(2), 183-202.

Draper, J.A., 1996, 'Confessional western text-centered biblical interpretation and an oral or residual-oral context', Semeia 73, 59-77.

Draper, J.A., 1999, 'Recovering oral performance from written text in Q', in R.A. Horsley \& J.A. Draper (eds.), Whoever hears you hears me: Prophets, performance and tradition in $Q$, pp. 175194, Trinity Press International, Harrisburg.

Dunn, J.D.G., 2003, 'Altering the default setting: Re-envisaging the early transmission of the Jesus tradition', New Testament Studies 49, 139-175.

Du Toit, A.B., 1980, 'Die historiese Jesus en die verkondigde Christus van die evangelies', in A.B. Du Toit (ed.), Handleiding by die Nuwe Testament, band 4. Die sinoptiese evangelies en Handelinge: Inleiding en teologie, pp. 255-281, NG Kerkboekhandel, Pretoria.

Du Toit, A.B., 1983, 'The historical Jesus and the proclaimed Christ of the gospels', in A.B. Du Toit (ed.), Guide to the New 
Testament, vol 4. The Synoptic Gospels and Acts: Introduction and theology, pp. 257-281, NG Kerkboekhandel, Pretoria.

Du Toit, A.B., 1993a, 'Die opkoms en huidige stand van die Nuwe-Testamentiese ondersoek in Suid-Afrika: Deel 1', HTS Teologiese Studies/HTS Theological Studies 49(3), 503-514.

Du Toit, A.B., 1993b, 'Die opkoms en huidige stand van die Nuwe-Testamentiese ondersoek in Suid-Afrika: Deel 2', HTS Teologiese Studies/Theological Studies 49(4), 786-809.

Du Toit, A.B., 1994, 'Die opkoms en huidige stand van die NuweTestamentiese ondersoek in Suid-Afrika: Deel 3 - 'n kritiese evaluasie', HTS Teologiese Studies/Theological Studies 50(3), 531-545.

Foley, J.M., 2006, 'Memory in oral tradition', in R.A. Horsley, J.A. Draper \& J.M. Foley (eds.), Performing the gospel: Orality, memory, and Mark, pp. 97-103, Fortress Press, Minneapolis.

Geyser, P.A., 1999, 'Historicity and theology, and the quest for historical Jesus', HTS Teologiese Studies/Theological Studies 55(4), 827-844.

Geyser, P.A., 2000, 'Hermeneutiese uitgangspunte in historiese Jesus navorsing: Metodologiese vooronderstellings', HTS Teologiese Studies/Theological Studies 56(4), 1146-1170.

Guy, J., 1983, The heretic: A study of the life of John William Colenso, 1814-1883, Ravan Press, Johannesburg.

Hearon, H.E., 2004, 'The implications of "orality" for studies of the biblical text', Oral Tradition 19(1), 96-107.

Holgate, D. \& Starr, R., 2006, SCM studyguide to Biblical hermeneutics, SCM Press, London.

Hund, J., 2004, 'African witchcraft and Western law: Psychological and cultural issues', Journal of Contemporary Religion 19(1), 67-84.

Jacobs, M., 1996, 'The relation between Jesus, Christ and Christian faith in current historical Jesus scholarship' Neotestamentica 30(1), 103-120.

The Kairos Document: Challenge to the church. A theological comment on the political crisis in South Africa, 2nd edn., 1986, Skotaville, Johannesburg.

Kelber, W.H., 2008, 'The oral-scribal-memorial arts of communication in early Christianity', in T. Thatcher (ed.), Jesus, the voice, and the text: Beyond the oral and the written gospel, pp. 234-262, Baylor University Press, Waco.

LeMarquand, G., 1997, 'The historical Jesus and African New Testament scholarship', in W.E. Arnal \& M. Desjardins (eds.), Whose historical Jesus?, pp. 161-180, Wilfrid Laurier University Press, Waterloo.

LeMarquand, G., 2000, 'New Testament exegesis in (modern) Africa', in G.O. West \& M. Dube (eds.), The Bible in Africa: Transactions, trajectories and trends, pp. 72-102, Brill, Leiden.

Le Roux, J.H., 1993, A story of two ways: Thirty years of Old Testament scholarship in South Africa. (OTE suppl. no. 2.), Verba Vitae, Pretoria.

Le Roux, J.H., 2008, 'He was a man of some importance and revered by many', Theologia Viatorum 32(2), 142-162.

Liebenberg, J., 1997, 'One Jesus, one quest - many images: Reflections on contemporary presuppositions about the history of Jesus', in C.W. Du Toit (ed.), Images of Jesus, pp. 38-63, University of South Africa, Pretoria.

Louw, J.P., 1973, 'Discourse analysis and the Greek New Testament', Bible Translator 24, 101-118.

Louw, J.P., 1982, Semantics of New Testament Greek, Fortress Press, Minneapolis.

Louw, J.P., 1992, 'Reading a text as discourse', in D.A. Black, K. Barnwell \& S. Levinsohn (eds.), Linguistics and New Testament interpretation: Essays on discourse analysis, pp. 1730, Broadman, Nashville.

Malherbe, A.J., 1992, 'Shortfalls despite vibrancy in NT study', CSD/SWO Bulletin 4(7), 18

Mofokeng, T., 1988, 'Black Christians, the Bible and liberation', Journal of Black Theology for Southern Africa 2(1), 34-42.

Mournet, T.C., 2005, Oral tradition and literary dependency: Variability and stability in the synoptic tradition and $Q$, Mohr Siebeck, Tübingen

Nicolson, R., 1990, A black future? Jesus and salvation in South Africa, SCM Press, London.
Niehaus, I., 2002, 'Perversion of power: Witchcraft and the sexuality of evil in the South African lowveld', Journal of Religion in Africa 32(3), 269.

Nolan, A., 1976, Jesus before Christianity: The gospel of liberation, David Philip, Cape Town.

Nolan, A., 1988, God in South Africa: The challenge of the Gospel, David Philip, Cape Town.

Nolan, A., 1994, 'Kairos theology', in J.W. De Gruchy \& C. Villa-Vicencio (eds.), Doing theology in context: South African perspectives, pp. 212-218, David Philip, Cape Town.

Nuttal, T. \& Wright, J., 2000, 'Probing the predicaments of academic history in contemporary South Africa', South African Historical Journal 42, 26-48.

Punt, J., 1998, "'My kingdom for a method": Methodological preoccupation in areas of South African New Testament scholarship', Neotestamentica 32(1), 135-160.

Scheffler, E.H., 1995, 'Jesus from a psychological perspective', Neotestamentica 29(2), 299-312.

Smit, D.J., 1996, 'Saints, disciples, friends? Recent South African perspectives on Christian ethics and the New Testament', Neotestamentica 30(1), 169-185.

Snyman, A.H., 1999, 'Hebrews 6.4-6 from a semiotic discourse perspective', in S.P. Porter \& J.T. Reed (eds.), Discourse analysis and the New Testament: Approaches and results, pp. 354-365, Sheffield Academic Press, Sheffield.

Strijdom, J., 1995, 'The "unconventionality" of Jesus from the perspective of a diverse audience: An evaluation of Crossan's historical Jesus', Neotestamentica 29(2), 313-324.

Strijdom, J., 1998, 'A historical Jesus hallucinating during his initial spirit-possession experience: A response to Stevan Davies' interpretation of Jesus' baptism by John', HTS Teologiese Studies/Theological Studies 54(3 \& 4), 588-602.

Strijdom, J., 2003, 'A Jesus to think with and live by: Story and ideology in Crossan's Jesus research', Religion $\mathcal{E}$ Theology 10(3), 267-295.

Taylor, N.H., 1999, 'Prolegomena to reconstructing the eschatological teaching of Jesus', Neotestamentica 33(1), 145 160.

Tracy, D., 1985, 'Lindbeck's new program for theology: A reflection', Thomist 49, 460-472.

Tracy, D., 1989, 'Some concluding reflections on the conference: Unity amidst diversity and conflict?', in H. Küng \& D. Tracy (eds.), Paradigm change in theology: A symposium for the future, pp. 461-471, T \& T Clark, Edinburgh.

Van Aarde, A.G., 1988, 'Jesus en die sosiaal-veragtes', HTS Teologiese Studies/Theological Studies 44(4), 829-846.

Van Aarde, A.G., 1992, 'The Evangelium Infantium, the abandonment of children and the infancy narrative in Matthew 1 and 2 in social scientific perspective', Society of Biblical Literature 31, 435-453.

Van Aarde, A.G., 1993a, 'Recent developments in South African Jesus research: From Andrie du Toit to Willem Vorster', HTS Teologiese Studies/Theological Studies 49(3), 397-423.

Van Aarde, A.G., 1993b, 'Recent developments in South African Jesus research: From Willem Vorster to Andries van Aarde', HTS Teologiese Studies/Theological Studies 49(4), 942-962.

Van Aarde, A.G., 1994, 'The epistemic status of the New Testament and the emancipatory living of the historical Jesus in engaged hermeneutics', Neotestamentica 28(2), 575596.

Van Aarde, A.G., 1995a, 'Die historiese Jesus, die Jesus-beweging en die vorming van die kerk', HTS Teologiese Studies/ Theological Studies 51(3), 623-644.

Van Aarde, A.G., 1995b, 'The "third quest" for the historical Jesus - where should it begin: With Jesus' relationship to the Baptiser, or with the nativity traditions?', Neotestamentica 29(2), 325-356

Van Aarde, A.G., 1997, 'The continued importance of Jesus', HTS Teologiese Studies/Theological Studies 53(3), 773-799.

Van Aarde, A.G., 1999, 'Dekonstruksie van dogma: 'n Eietydse ondersoek na die spore van die leer van die twee nature van Jesus', HTS Teologiese Studies/Theological Studies 55(2\&3), $437-470$ 
Van Aarde, A.G., 2000a, 'The carpenter's son (Mt 13:55): Joseph and Jesus in the Gospel of Matthew and other texts', Neotestamentica 34(1), 173-190.

Van Aarde, A.G., 2000b, 'Die relevansie van die historiese Jesusondersoek vir kerklike teologie', HTS Teologiese Studies/ Theological Studies 56(2\&3), 549-571.

Van Aarde, A.G., 2001a, "The "cause of Jesus" (Sache Jesu) as the canon behind the canon', HTS Teologiese Studies/Theological Studies 57, 148-171.

Van Aarde, A.G., 2001b, Fatherless in Galilee: Jesus as child of God, Trinity Press International, Harrisburg.

Van Aarde, A.G., 2002, 'Methods and models in the quest for the historical Jesus: Historical criticism and/or social scientific criticism', HTS Teologiese Studies/HTS Theological Studies 58(2), 419-439.

Van Aarde, A.G., 2003, 'Does historical Jesus research have a future?', Verbum et Ecclesia 24(2), 533-556.

Van Aarde, A.G., 2004, 'Postmoderne epistemologie en postkoloniale hermeneutiek', HTS Teologiese Studies/ Theological Studies 60(3), 1105-1125.

Van Aarde, A.G., 2008, "Anthropological rabbits" and "positivistic ducks": An experiential reflection on Pieter Craffert's "shamanic Jesus"', HTS Teologiese Studies/ Theological Studies 64(2), 767-798.

Van Eck, E., 1996, 'The baptism of Jesus in Mark: A status transformation ritual', Neotestamentica 30(1), 187-216.

Van Eck, E., 2004, 'Die opstanding van Jesus Christ as historiese gebeure', HTS Teologiese Studies/Theological Studies 60(3), 1173-1200.

Van Eck, E., 2007, 'The tenants in the vineyard (GThom 65/ Mark 12:1-12): A realistic and social-scientific reading', HTS Teologiese Studies/Theological Studies 63(3), 909-936.

Van Zyl, H.C., 2000, 'Die stand van Nuwe-Testamentiese navorsing in Suid-Afrika. Enkele tendense in die jare 19931999, Acta Theologica, suppl. 1, 169-236.

Venter, R., 1995, 'Historical Jesus research and systematic theology: From alienation to a common vision', Neotestamentica 29(2), 357-392.

Vorster, J.N., 2008, 'Rhetorically reflecting on "Jesus" research', Theologia Viatorum 32(2), 3-48.

Vorster, W.S., 1980, 'Mark: Collector, redactor, author, narrator', Journal of Theology for Southern Africa 31, 46-61.
Vorster, W.S., 1981, 'On the origins of Christianity: A religiohistorical perspective', in W.S. Vorster, Christianity among the religions, pp. 36-56, University of South Africa, Pretoria.

Vorster, W.S., 1982a, 'Formgeschichte' en 'Redaktionsgeschichte', in A.F.J. Klijn (ed.), Inleiding tot de studie van het Nieuwe Testament, pp. 94-111, Kok, Kampen.

Vorster, W.S., 1982b, 'Redaction, contextualization and the sayings of Jesus', in J. Delobel (ed.), Logia. Les paroles de Jesus - the sayings of Jesus, pp. 491-500, University Press, Leuven.

Vorster, W.S., 1983, 'Kerygma/history and the gospel genre', New Testament Studies 29, 87-95.

Vorster, W.S., 1984, 'The use of Scripture and the NG Kerk: A shift of paradigm or of values?', in J.W. Hofmeyr \& W.S. Vorster (eds.), New faces of Africa, pp. 204-219, University of South Africa, Pretoria.

Vorster, W.S., 1989, 'Intertextuality and Redaktionsgeschichte', in S. Draisma (ed.), Intertextuality in Biblical writings, pp. 1526, Kok, Kampen.

Vorster, W.S., 1990, 'The function of metaphorical and apocalyptic language about the unobservable in the teaching of Jesus', in T.W. Jennings (ed.), Text and logos: The humanistic interpretation of the New Testament, pp. 33-51, Scholars Press, Atlanta.

Vorster, W.S., 1994, 'The relevance of Jesus research for the "new" South Africa', in J. Mouton \& B. Lategan (eds.), The relevance of theology for the 1990s, pp. 619-633, Human Sciences Research Council, Pretoria.

Vorster, W.S., 1999, Speaking of Jesus: Essays on biblical language, gospel narrative and the historical Jesus, Brill, Leiden.

Vorster, W.S. \& Botha, P.J.J., 1992, 'The Jewishness of Jesus: Presuppositions and the historical study of the New Testament'., Research report, Human Sciences Research Council: Investigation into Research Methodology.

Wanamaker, C.A., 1996, 'The historical Jesus today: A reconsideration of the foundation of christology', Journal of Theology for Southern Africa 94, 3-17.

Wanamaker, C.A., 1997, 'Jesus the ancestor: Reading the story of Jesus from an African Christian perspective', Scriptura 63, 281-298.

West, G.O. 2000. Mapping African biblical interpretation: A tentative sketch, in West, G.O. \& Dube, M. (eds), The Bible in Africa: Transactions, trajectories and trends, pp. 29-53, Brill, Leiden. 